\title{
Pengenalan Citra Tanda Tangan Menggunakan Metode 2D-LDA dan Euclidean Distance
}

\author{
Signature Image Recognition 2DLDA Method and Euclidean Distance
}

\author{
Danar Putra Pamungkas*1, Fajar Rohman Hariri \\ ${ }^{1,2}$ Universitas Nusantara PGRI Kediri \\ E-mail: *1danar@unpkediri.ac.id, ${ }^{2}$ dosendeso@gmail.com
}

\begin{abstract}
Abstrak
Kelemahan sistem manual dalam identifikasi tanda tangan adalah si pemeriksa tanda tangan harus teliti dalam melakukan pencocokan untuk menghindari kesalahan. Oleh karena itu untuk mengatasi kelemahan pencocokan tanda tangan secara manual, proses pencocokan tanda tangan perlu dilakukan secara otomastis dengan sistem komputer sehingga diharapkan mempermudah dalam identifikasi tanda tangan seseorang. Pada penelitian ini peneliti menggunakan metode 2DLDA dan Euclidean Distance untuk pengenalan tanda tangan dengan sistem komputer. Metode 2DLDA untuk ektraksi fitur citra tanda tangan dan metode Euclidean Distance untuk klasifikasi citra tanda tangan. Data citra tanda tangan yang digunakan berukuran 50x50, 100x100, 150x150, 200x200 dan 250x250 piksel. Hasil dari uji coba penelitian ini adalah akurasi pengenalan citra tanda tangan menggunakan metode 2DLDA mencapai 88\% dan ratarata akurasi $81 \%$. Akurasi optimal pengenalan citra tanda tangan dengan metode 2DLDA terjadi pada penggunaan data citra berukuran $50 x 50$ piksel dengan akurasi $88 \%$ dan kecepatan 0.20126 detik.
\end{abstract}

Kata Kunci - tanda tangan, 2DLDA, Euclidean Distance

\begin{abstract}
The manual system in the identification of the examiner's signature is the signature must be meticulous in doing matching to avoid mistakes. Therefore, to overcome the disadvantages of signature matching manually, signature matching process needs to be done should automatically with a computer system that is expected to facilitate the identification of a person's signature. In this study, researchers used a method 2DLDA and Euclidean Distance to the introduction of a signature with a computer system. 2DLDA methods to extract image features the signature and Euclidean Distance method for image classification signature. The image data signature used measuring 50x50,100x100, 150x150,200x200 and 250x250 pixels. The results of this research trial is a signature image recognition accuracy using $2 D L D A$ reaches $88 \%$ and an average accuracy of $81 \%$. Optimum accuracy signature image recognition method 2DLDA occurs in the use of image data size of $50 \times 50$ pixels with $88 \%$ accuracy and speed 0.20126 seconds
\end{abstract}

Keywords - signature, 2DLDA, Euclidean Distance 


\section{PENDAHULUAN}

Tanda tangan adalah hasil proses menulis seseorang yang bersifat khusus sebagai substansi simbolik. Tanda tangan merupakan bentuk yang paling banyak digunakan untuk identifikasi seseorang [1]. Pada umumnya pengenalan tanda tangan dilakukan secara manual oleh seseorang dengan mencocokkan secara langsung tanda tangan yang sah dengan tanda tangan yang dilakukan saat itu. Contoh-contoh tanda tangan setiap orang umumnya identik namun tidak sama, artinya tanda tangan seseorang sering berubah-ubah setiap waktu. Perubahan ini menyangkut posisi, ukuran maupun faktor tekanan tanda tangan [2]. Kelemahan sistem manual dalam identifikasi tanda tangan adalah si pemeriksa tanda tangan harus teliti dalam melakukan pencocokan untuk menghindari kesalahan. Oleh karena itu untuk mengatasi kelemahan pencocokan tanda tangan secara manual, proses pencocokan tanda tangan perlu dilakukan secara otomastis dengan sistem komputer sehingga diharapkan mempermudah dalam identifikasi tanda tangan seseorang.

Pengenalan citra tanda tangan merupakan salah satu bidang pengenalan pola (pattern recognition). Secara umum proses pengenalan pola dengan mengekstraksi suatu citra untuk mendapatkan ciri citra tersebut, salah satu metode untuk ekstraksi citra adalah Linear Discriminant Analysis (LDA). Pada tahun 1991 diperkenalkan metode LDA oleh Cheng dkk. Metode LDA berusaha untuk memisahkan antar kelas dengan meminimalkan jarak antar matrik sebaran within class. Jika dimensi data jauh lebih tinggi daripada jumlah sampel training maka menyebabkan within class menjadi singular yang merupakan kelemahan dari LDA [3]. Medote Two Dimensional Linear Discriminant Analysis (2DLDA) dikembangkan untuk mengatasi kelemahan dari metode tersebut. Metode 2DLDA merupakan metode pengembangan dan varian baru dari metode LDA. Peforma metode 2DLDA lebih baik dari metode LDA pada penggunaan data training yang sedikit [4].

Penelitian pengenalan pola menggunakan metode 2DLDA dengan objek citra senyuman oleh Wahyuningrum. Penelitian tersebut menghasilkan akurasi pengenalan citra senyuman berdasar Aesthetic Dentistry sebesar 96,67\% [5]. Akurasi pengenalan citra wajah menggunakan metode 2DLDA dan digabungkan dengan metode Support Vector Machine mencapai 84,18\% sampai 100\% [6]. Penelitian mengenai pencocokan tanda tangan secara otomatis dilakukan oleh Johannes Putra Abri Sipahutar. Penelitian tersebut menggunakan metode Backpropagation dan Kohonen sebagai pembanding. Kedua metode tersebut diterapkan pada alat Smartcard-RFID dan pen-tablet. Penggunaan metode Backpropagation lebih baik dibandingkan dengan metode Kohonen yaitu diatas rata-rata $75 \%$ [7]. Tidak konsistennya pangguna dalam memasukkan tada tangan dalam pen-tablet menyebabkan rendahnya akurasi. Metode 2DLDA mempunyai rata-rata akurasi untuk pengenalan tanda tangan menggunakan ukuran citra 100x100 piksel adalah $78.27 \%$ dan rata-rata kecepatan proses pengenalan yaitu 0.2605504 detik $74,33 \%$ [8]. Pada penelitian tersebut menggunakan data citra tanda tangan dengan enam kondisi yang berbeda dan hanya menggunakan data citra berukuran $100 \times 100$ piksel. Penelitian tersebut menyarankan menggunakan ukuran citra yang lebih besar untuk mengetahui perbandingan tingkat akurasi dengan ukuran data citra yang digunakan. Oleh karena itu peneliti ingin mengetahui perbandingan tingkat akurasi metode 2DLDA terhadap ukuran data citra tanda tangan yang digunakan.

Peneliti menggunakan data citra tanda tangan yang bervariasi yaitu 50x50, 100x100,150x150, 200x200 dan 250x250 piksel dan hanya menggunakan kondisi citra tanda tangan yaitu kertas putih polos. Peneliti juga akan membandingkan akurasi dengan kecepatan pengenalan citra tanda tangan untuk mengetahui akurasi yang optimal dalam penggunaan data citra tanda tangan. Penelitian ini membutuhkan suatu propotype yang akan digunakan untuk melakukan ujicoba. Prototype yang dibuat memiliki fungsionalitas yang terbatas tidak menggunakan Graphical User Interface hanya menggunakan jendela command line pada software Matlab 2013a. Untuk mengetahui kecepatan proses pengenalan citra tanda tangan peneliti menggunakan fungsi tic dan toc pada Matlab2013a. Proses treshold menggunakan metode Otsu 


\section{METODE PENELITIAN}

\subsection{Data Tanda Tangan}

Data citra yang digunakan dalam penelitian ini sebanyak 1000. Data tanda tangan tersebut diambil dari mahasiswa di lingkungan Universitas Nusantara PGRI Kediri. Jumlah responden sepuluh, setiap responden diambil data tanda tangan sebanyak 20. Tanda tangan dilakukan menggunakan ball point warna hitam dengan ketebalan antara $0.5 \mathrm{~mm}$ sampai $1 \mathrm{~mm}$ pada kertas putih polos A4 yang sudah dipetakan. Kemudian dilakukan scanning dan pemotongan gambar, setelah itu dilakukan resize untuk data citra tanda tangan berukuran 50x50 piksel, 100x100 piksel, 150x150 piksel, 200x200 piksel dan 250 x250 piksel. Gambar 1 merupakan salah satu contoh data citra tanda tangan hasil pemotongan dari citra scan.

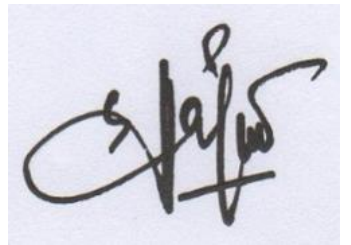

Gambar 1. Contoh data citra tanda tangan

\section{2. $2 D L D A$}

Metode 2DLDA merupakan pengembangan dari metode LDA. Alur kerja dari metode 2DLDA hampir sama dengan metode LDA, perbedaan utama antara metode LDA dan 2DLDA adalah cara representasi data, jika LDA data direpresentasikan menjadi vector atau matrik satu dimensi maka metode 2DLDA direpresentasikan menjadi matrik dua dimensi [9]. Langkah pertama adalah mecari mean dari beberapa data, missal ada dua data citra $\mathrm{x} 1$ dan $\mathrm{x} 2$ dengan persamaan 1. [10]

$$
\mu_{1}=\mu_{1}=\frac{1}{N_{1}} \sum_{x \in \omega_{1}} x, \mu_{2}=\frac{1}{N_{2}} \sum_{x \in \omega_{2}} x
$$

Persamaan 2 digunakan untuk mencari matrik covarian dari kedua data setelah mean didapatkan [10].

$$
S_{2}=\sum_{x \in \omega_{2}}\left(x-\mu_{2}\right)\left(x-\mu_{2}\right)^{T}
$$

Kemudian setelah mendapatkan matrik covarian, langkah selanjutnya mencari within class scatter matrix dengan persamaan 3 [10].

$$
S_{w}=S_{1}+S_{2}
$$

Persamaan 4 digunakan untuk mencari between class scatter matrix [9].

$$
\left.S_{B}=\left(\mu_{1}-\mu_{2}\right)\left(\mu_{1}-\mu_{2}\right)^{T}\right)
$$

Kemudian membentuk matrik proyeksi (W) yang digunakan untuk proyeksi data baru (data testing) menggunakan persamaan 5 [10].

$$
S_{W}^{-1} S_{B} W=\lambda W
$$

\subsection{Euclidean Distence}

Proses klasisfikasi data tanda tangan menggunakan metode klasifikasi tetangga terdekatnya (Euclidean Distance). Metode Euclidean Distance menghitung akar dari kuadrat perdedaan 2 vektor (root squere different between 2 vectors) [11]. Rumus penghitungan jarak ditulis sebagai berikut: 


$$
d_{e}=\sqrt{\sum_{k=1}^{m}\left(f d_{i, k}-k_{j}\right)^{2}}
$$

Keterangan :

$\mathrm{d}_{\mathrm{e}} \quad$ : jarak euclidean

$f_{i} \quad$ : bobot citra pelatihan

$\boldsymbol{k}_{j} \quad$ : data bobot wajah test

$\boldsymbol{m} \quad$ : jumlah data pelatihan

Bobot paling kecil dari Euclidean $\left(\boldsymbol{d}_{\boldsymbol{e}}\right)$ akan digunakan sebagai nilai fitness dari sebuah citra tanda tangan yang digunakan untuk pengenalan citra tanda tangan. Untuk mencari nilai akurasi dengan cara membandingkan jumlah data tanda tangan yang berhasil dikenalai dengan jumlah data testing yang digunakan, kemudian dikalikan 100\% seperti persamaan 7.

$$
N a=\frac{D t-E r}{D t} \times 100 \%
$$

Keterangan :

$\mathbf{N a}$ : nilai akurasi

Er : jumlah kesalahan pengenalan citra

Dt : jumlah data testing

\subsection{Perancangan Sistem}

Penelitian ini terbagi menjadi dua proses yaitu pra proses dan implentasi. Pra proses meliputi mengubah ukuran data citra tanda tangan (resize image), konversi data citra RGB ke Grayscale dan melakukan threshold pada citra tanda tangan grayscale. Pada implementasi meliputi reduksi dimensi data citra, pembentukan data citra training, memaukkan data citra testing, reduksi dimensi data citra testing dan pencocokan data citra tanda tangan yang mengsilkan akurasi dari metode 2DLDA. Alur proses tersebut dapat dilihat pada Gambar 2.

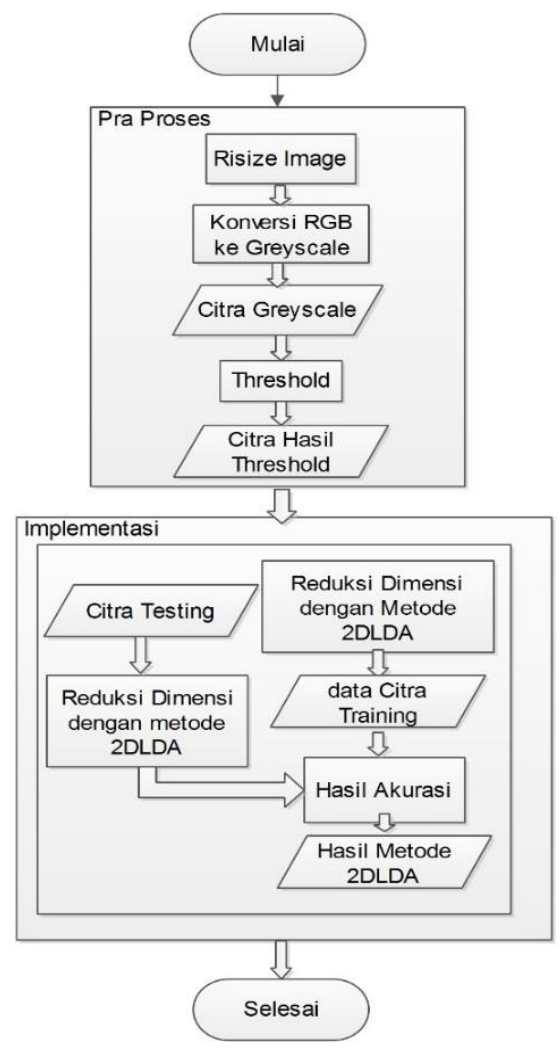

Gambar 2. Alur penelitian 


\subsection{Pra Proses}

\subsubsection{Resize Image}

Sebelum data digunakan data harus dilakukan tahap pra proses untuk memudahkan langkah selanjutnya. Pada tahap ini proses yang dilakukan adalah mengubah ukuran gambar data tanda tangan dari ukuran asli menjadi 50x50 piksel, 100x100 piksel, 150x150 piksel, 200x200 piksel dan 250x250 piksel. Untuk mempermudah merubah ukuran citra tanda tangan sebanyak 1000 data pada penelitian ini menggunakan aplikasi Caesium Image Compresor 1.7 Protable. Misalnya pada Gambar 3(a) data tanda tangan yang diambil dari kertas putih polos berukuran 300 x 300 piksel dilakukan proses resize image menjadi Gambar 3(b) berukuran 150x150 piksel.

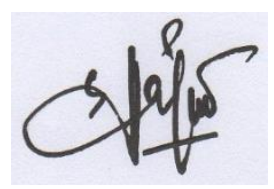

(a)

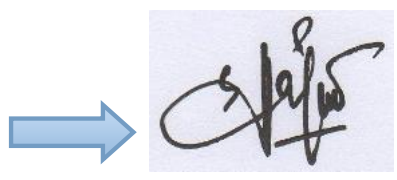

(b)

Gambar 3. Resize Image

Gambar (a) Citra ukuran asli

Gambar (b) Citra hasil resize

\subsubsection{Konversi $R G B$ ke Grayscale}

Setelah data melalui proses resize image langkah selanjutanya konversi gambar true color yang memmiliki tiga atribut yaitu Red Green Blue (RGB) menjadi gambar keabuan (Grayscale) yang memiliki satu atribut. Misalnya diketahui gambar hasil proses resize pada Gambar 4(a) memiliki tiga atribut Red, Green dan Blue maka akan dilakukan proses konversi gambar menjadi grayscale pada Gambar 4(b).

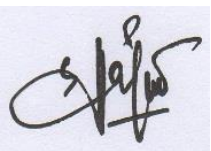

(a)

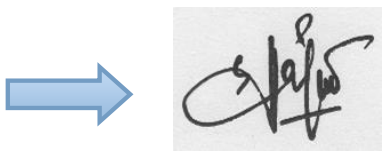

(b)

Gambar 4. Konversi Grayscale Gambar (a) Citra RGB

Gambar (b) Citra Grayscale

\subsubsection{Threshold}

Setelah data citra sudah menjadi grayscale selanjutnya dilakukan thresholding atau mengubah gambar dari derajat keabuan menjadi gambar hitam putih. Metode threshold yang digunakan adalah metode Otsu. Misalnya diketahui data Gambar 5(a) hasil konversi grayscale kemudian dilakukan proses threshold menjadi data gambar hitam putih seperti pada Gambar 5(b).

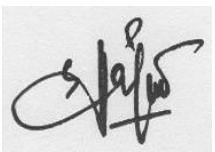

(a)

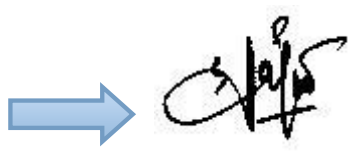

(b)

Gambar 5. Proses Threshold

Gambar (a) Citra Grayscale

Gambar (b) Citra hitam putih 


\subsection{Implementasi}

\subsubsection{Pembentukan Matrik Data Latih}

Setiap data latih pada tahap ini dilakukan pembentukan matrik $(m \times n)$ sebanyak jumlah data latih yang digunakan. Misalnya jika data latih yang digunakan sebanyak 100 dan setiap data citra berukuran 100x100 piksel maka data yang terbentuk adalah 100x100x100. Tabel 1 merupakan cuplikan matrik data latih ttd001.jpg dari kolom ke-1 sampai 10 dan baris ke-1 sampai 10. Setiap cell mempunyai nilai antara $0-255$, nilai 0 representasi dari warna hitam sedangkan nilai 255 representasi dari warna putih. Semakin redah nilainya semakin gelap warnanya atau mendekati warna hitam. Matrik data latih tersebut yang akan digunakan untuk membentuk matrik proyeksi pada metode 2DLDA.

Tabel 1. Cuplikan matrik data latih

\begin{tabular}{|l|l|l|l|l|l|l|l|l|l|}
\hline 255 & 255 & 255 & 255 & 255 & 255 & 255 & 255 & 255 & 255 \\
\hline 255 & 255 & 255 & 255 & 255 & 255 & 255 & 255 & 255 & 255 \\
\hline 255 & 255 & 255 & 255 & 255 & 255 & 255 & 255 & 255 & 255 \\
\hline 255 & 255 & 255 & 255 & 255 & 255 & 255 & 255 & 255 & 255 \\
\hline 255 & 255 & 255 & 255 & 255 & 255 & 255 & 255 & 255 & 255 \\
\hline 255 & 255 & 255 & 255 & 255 & 255 & 255 & 255 & 255 & 255 \\
\hline 255 & 255 & 255 & 255 & 255 & 255 & 255 & 255 & 255 & 255 \\
\hline 255 & 255 & 255 & 255 & 255 & 255 & 255 & 255 & 255 & 255 \\
\hline 255 & 255 & 255 & 255 & 255 & 255 & 255 & 255 & 255 & 255 \\
\hline 255 & 255 & 255 & 255 & 255 & 255 & 255 & 255 & 255 & 255 \\
\hline
\end{tabular}

\subsubsection{Pembentukan Matrik Fitur Data Latih 2DLDA}

Pada tahap ini metode 2DLDA melakukan ektraksi fitur dari matrik data latih yang terbentuk sebelumnya. Proses ini menghasilkan dua matrik baru yaitu matrik score dengan ukuran (100x100) yang merupakan matrik fitur data training dan matrik proyeksi berukuran (100x9x100). Potongan matrik score kolom ke-1 sampai ke-5 dan baris ke-1 sampai ke-8 dapat dilihat pada Tabel 2.

Tabel 2. Cuplikan matrik ektraksi fitur 2DLDA

\begin{tabular}{|l|l|l|l|l|}
\hline-0.39089 & 0.268732 & 0.400849 & 0.004235 & -0.29972 \\
\hline-0.39566 & -0.0485 & 0.254505 & -0.16986 & 0.072051 \\
\hline-0.27052 & -0.23852 & -0.01041 & 0.02423 & 0.005641 \\
\hline-0.00509 & -0.01733 & -0.12564 & -0.02425 & -0.02275 \\
\hline 0.193496 & 0.015791 & -0.16074 & 0.104413 & 0.06198 \\
\hline 0.130382 & 0.087024 & 0.100192 & -0.04531 & -0.03477 \\
\hline 0.012737 & -0.00382 & 0.096129 & -0.02561 & 0.00724 \\
\hline 0.023266 & -0.03101 & 0.037281 & -0.03834 & 0.026967 \\
\hline
\end{tabular}

Pada Tabel 3 merupakan potongan matrik proyeksi 2DLDA dari kolom ke-1 sampai ke5 dan baris ke-1 sampai ke-10. Matrik proyeksi merupakan matrik yang digunakan untuk melakukan proyeksi data baru atau data testing. Kemudian melakukan pengukuran matrik score dengan matrik testing yang telah diproyeksikan sebelumnya dengan metode Euclidian distance. 
Citec Journal, Vol. 3, No. 4, Agustus 2016 - Oktober 2016

Tabel 3. Cuplikan matrik proyeksi 2DLDA

\begin{tabular}{|l|l|l|l|l|}
\hline-1.682 & 37.6073 & 16.7712 & 41.2119 & 5.0326 \\
\hline-24.8189 & 28.6349 & 13.0532 & 147.0046 & -25.6913 \\
\hline-14.357 & -192.787 & 17.6591 & 136.7384 & -18.9352 \\
\hline-8.0792 & -224.545 & 24.6203 & 81.4338 & -1.7556 \\
\hline-1.5696 & -36.6184 & -270.555 & 77.4675 & -1.8411 \\
\hline-10.807 & -1.7556 & -325.218 & 154.5588 & -1.8795 \\
\hline-14.1752 & -1.8411 & -298.355 & 121.5123 & -4.6702 \\
\hline-6.7397 & -1.8795 & -77.6568 & 152.0819 & 2.7524 \\
\hline-14.7255 & 1.3203 & -9.9997 & 106.2377 & 0.9111 \\
\hline-9.4815 & 0.8487 & 7.37 & 85.8592 & -43.721 \\
\hline
\end{tabular}

\subsubsection{Pengukuran Jarak dengan Euclidean Distance}

Tahap akhir adalah melakukan pengukuran jarak antara matrik score dengan matrik proyeksi data testing yang sebelumnya sudah diproyeksi dengan matrik proyeksi data training. Jumlah data citra tanda tangan yang mempunyai kemiripan paling besar tiap kelasnya akan dihitung presentase dengan jumlah data testing yang digunakan. Untuk pengukuran jarak terdekat menggunakan persamaan 6. Pada Tabel 4 merupakan merupakan cuplikan data hasil perhitungan Euclidean Distance enam data dari 100 data testing yang digunakan. Semakin kecil nilainya maka semakin dekat jarak dengan citra yang dicocokan.

Tabel 4. Cuplikan data hasil Euclidean Distance

\begin{tabular}{|l|l|l|l|l|}
\hline Data ke-1 & Data ke-2 & Data ke-3 & Data ke-4 & Data ke-5 \\
\hline 14875.84 & 15270.4 & 15854.21 & 15141.99 & 14600.88 \\
\hline
\end{tabular}

\section{HASIL DAN PEMBAHASAN}

\subsection{Skenario Uji Coba}

Metode analisa data hasil penelitian ini dilakukan dengan menggunakan analisa statistik. Data sampel penelitian menggunakan data citra tanda tangan sebanyak 1000 yang didapat dari 10 partisipan, masing-masing 20 data diambil dari kertas putih polos, kemudian dilakukan scanning, pemotongan dan mengubah ukuran citra menjadi 50x50, 100x100, 150x150, 200x200 dan $250 \times 250$ piksel. Untuk mendapatkan hasil analisa maka dibuatlah skenario uji coba yang akan digunakan untuk analisa data, setiap skenario menggunakan 200 data. Berikut adalah skenario uji coba yang dirujuk pada Tabel 5.

Tabel 5. Skenario Uji Coba

\begin{tabular}{|l|l|l|}
\hline Skenario & Ukuran data citra (piksel) & Training \% : testing \% \\
\hline 1 & $50 \times 50$ & $50: 50$ \\
\hline 2 & $100 \times 100$ & $50: 50$ \\
\hline 3 & $150 \times 150$ & $50: 50$ \\
\hline 4 & $200 \times 200$ & $50: 50$ \\
\hline 5 & $250 \times 250$ & $50: 50$ \\
\hline
\end{tabular}

Untuk mengukur kecepatan pengenalan penulis menggunakan fungsi tic dan toc pada Matlab. Fungsi tic pada matlab adalah untuk memulai pencatatan waktu sedangkan toc untuk 
membaca waktu pencatatan. Fungsi tic diletakan pada awal source code metode 2DLDA dan fungsi toc diletakan pada akhir source code metode Euclidean Distance sehingga bisa didapatkan waktu eksekusi pengenalan citra tanda tangan. Waktu yang didapat dari toc digunakan untuk mengetahui berapa kecepatan pengenalan citra tanda tangan.

\subsection{Implementasi}

Prototype dibangun menggunakan software Matlab 2013a. Laptop yang digunakan untuk ujicoba menggunakan sistem operasi Windows 7 Profesional Service Pack 1 dengan spesifikasi RAM 4GB CPU Intel Core i3 2,4 GHz. Cara penggunaannya yaitu mengetikan tesisttd(a,b,c) dimana ' $a$ ' adalah presentasi data training, 'b' adalah presentase data testing dan ' $c$ ' merupan nomor skenario. Setelah menuliskan perintah tesisttd(a,b,c) kemudian tekan Enter, sistem secara otomatis melakukan pengambilan data training dan testing, pembentukan data training metode 2DLDA, ekstrasksi fitur, mencari kemiripan menggunakan Euclidean Distance. Prototype akan menampilkan hasil akurasi pengenalan citra tanda tangan dan kecepatan proses pengenalan seperti pada Gambar 6.

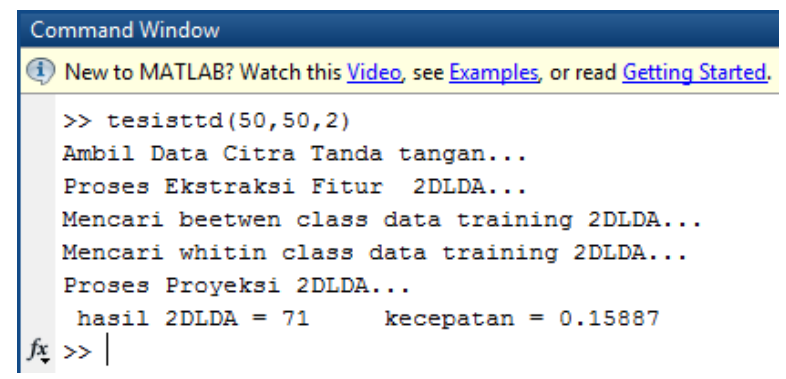

Gambar 6. Contoh ujicoba skenario 2

Pada Gambar 6 merupakan contoh uji coba menggunakan skenario nomor 2 dengan ukuran data citra 100x100 piksel dan menggunakan data training sebanyak $100(50 \%)$ testing 100 (50\%). Pada hasil uji coba tersebut akurasi pengenalan citra tanda tangan menggunakan metode 2DLDA $71 \%$ dengan kecepatan proses pengenalan 0.15887 detik.

\subsection{Analisa Hasil Uji Coba}

Setelah dilakukan uji coba dengan skenario pada Tabel 6, akurasi tertinggi menggunakan data berukuran 50x50 piksel yaitu 88\% dengan kecepatan 0.20126 detik. Sedangkan akurasi terendah menggunakan data citra berukuran 100x100 piksel yaitu akurasi $71 \%$ dan kecepatan 0.26515 detik. Hasil uji coba keseluruhan dapat dilihat pada Tabel 6. Rata-rata akurasi dari lima skenario uji coba adalah $81 \%$. Dari hasil uji coba ternyata ukuran citra tanda tangan mempengaruhi akurasi pengenalan. Semakin besar ukuran citra tanda tangan belum tentu semakin tinggi akurasi pengenalan citra tanda tangan.

Tabel 6. Hasil Uji Coba

\begin{tabular}{|l|l|l|l|}
\hline No & \multicolumn{1}{|c|}{ Resolusi gambar } & \multicolumn{1}{|c}{ Akurasi } & \multicolumn{1}{|c|}{ Kecepatan (detik) } \\
\hline 1 & $50 \times 50 \mathrm{px}$ & $88 \%$ & 0.20126 \\
\hline 2 & $100 \times 100 \mathrm{px}$ & $71 \%$ & 0.26515 \\
\hline 3 & $150 \times 150 \mathrm{px}$ & $87 \%$ & 0.33126 \\
\hline 4 & $200 \times 200 \mathrm{px}$ & $76 \%$ & 0.42402 \\
\hline 5 & $250 \times 250 \mathrm{px}$ & $83 \%$ & 0.56439 \\
\hline
\end{tabular}

Kecepatan proses pengenalan citra tanda tangan adalah 0.20126 detik pada skenario satu menggunakan ukuran data citra 50x50 piksel, sedangkan paling lambat adalah 0.56439 detik pada 
skenario lima menggunakan data citra 250x250 piksel. Semakin besar ukuran citra tanda tangan proses pengenalan semakin lama, karena matrik yang terbentuk pada proses training dan testing semakin besar membuat komputasi lebih lama. Pada Gambar 7 terlihat jelas perbedaan kecepatan proses pengenalan citra tanda tangan dengan ukuran data citra tanda tangan yang berbeda. Dari data hasil uji coba pada Tabel 6, akurasi optimal pengenalan citra tanda tangan dengan metode 2DLDA terjadi pada penggunaan data citra berukuran 50x50 piksel. Hal itu bisa disimpulkan karena akurasinya paling tinggi dibanding penggunaan data citra 100x100, 150x150, 200x200 dan 250x250 piksel yaitu 88\% dan kecepatanya juga paling cepat yaitu 0.20126 detik. Hal ini terjadi karena metode 2D-LDA memiliki kemampuan mengoptimalkan diskriminan data yaitu dapat memisahkan data-data yang ada, mengelompokkan vektor data dari suatu kelas yang sama dan memisahkan dari suatu kelas data yang berbeda. Meskipun data yang digunakan mempunyai dimensi yang kecil yaitu 50x50 piksel mampu menghasilkan akurasi pengenalan citra tanda tangan lebih baik dari citra yang berukuran dimensi lebih besar karena vektor data dari kelas yang sama semakin banyak terbentuk. Jika semakin besar dimensi data yang digunakan maka semakin banyak kelas data yang berbeda terbentuk maka semakin banyak pemisahan data yang terjadi dan semakin banyak vektor data kelas yang berbeda terbentuk yang dapat mempengaruhi tingkat akurasi pengenalan citra tanda tangan. Pada gambar 8 merupakan perbandingan citra tanda tangan hasil metode Otsu mulai dari 50x50 piksel sampai dengan 250x250 piksel.

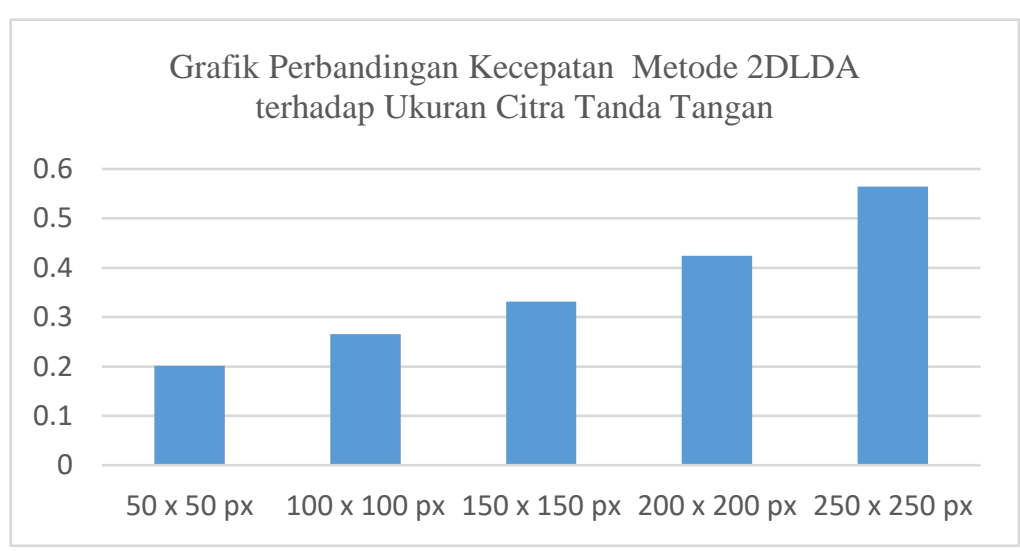

Gambar 7. Grafik perbandingan kecepatan.

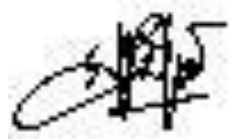

(a)

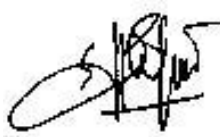

(b)

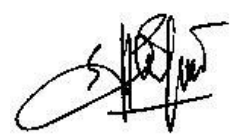

(c)

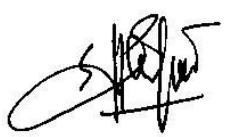

(d)

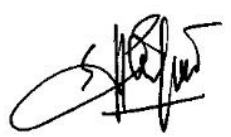

(e)

Gambar 8. Perbandingan hasil threshold Otsu

Gambar 8(a). Citra 50x50 piksel

Gambar 8(b). Citra 100x100 piksel

Gambar 8(c). Citra 150x150 piksel

Gambar 8(d). Citra 200x200 piksel

Gambar 8(e). Citra 250x250 piksel 


\section{KESIMPULAN}

Dari hasil uji coba yang telah dilakukan maka didapatkan kesimpulan seperti berikut ini:

1. Akurasi pengenalan citra tanda tangan menggunakan metode 2DLDA mencapai $88 \%$ dan rata-rata akurasi $81 \%$

2. Akurasi optimal pengenalan citra tanda tangan dengan metode 2DLDA terjadi pada penggunaan data citra berukuran 50x50 piksel dengan akurasi 88\% dan kecepatan 0.20126 detik.

\section{SARAN}

Dari hasil ujicoba pengenalan citra tanda tangan dengan menggunakan 2DLDA untuk saran-saranya adalah sebagai berikut:

1. Diharapkan penelitian selanjutnya menggunakan data yang mempunyai noise banyak.

2. Diharapkan penelitian selanjutnya menggunakan presentase data training yang berbeda pada setiap skenario untuk mengetahui penggunaan data training yang optimal.

3. Diharapkan penelitian selanjutnya menggunakan data tanda tangan dengan kemiringan yang berbeda untuk mengetahui akurasi optimal pada penggunaan toleransi derajat kemiringan tanda tangan.

\section{DAFTAR PUSTAKA}

[1] Abbas, R., 1994, Backpropagation Networks Prototype for Off-Line Signature Verification, www.cs.rmit.edu.au/ vc/papers/abbas-mbc.ps.gz, diakses tanggal 10 Oktober 2014

[2] Djunaidy, A., Soelaiman, R., Rusdianah, R., 2000, Verifikasi Tanda Tangan Berdasarkan Interprestasi Struktural dari Arah Gerak dan Tekanannya, http://repository.gunadarma.ac.id/ 1195/1/VERIFIKASI\%20TANDA\%20TANGAN\%20BERDASARKAN\%20INTERPRETASI\% 20STRUKTURAL\%20BERDASARKAN\%20INTERPEST\%20STRUKTURAL\%20DARI\%20 ARAH\%20GERAK\%20DAN\%20TEKANANNYA_UG.pdf, diakses tanggal 7 September 2014

[3] Belhumeur, P. N., Hespanha J. P., Kriegman D. J., 1997, Eigenfaces vs Fisherfaces: Regcognition Using Class Specific Linear Projection, vision.ucsd.edu/kriegmangrp/papers/pami97.pdf, diakses tanggal 4 November 2014

[4] Zheng, W. S., Lai, J.H., Li, S. Z., 2007, 1D-LDA versus 2D-LDA: When Is Vector-based Linear Discriminant Analysis Better than Matrix-based?, http://www.eecs.qmul.ac.uk/ jason/ Research/PreprintVersion/1D-LDA_vs._2D-LDA_Preprint.pdf, diakses tanggal 13 April 2015

[5] Wahyuningrum, R.T., Damayanti, F., 2010, Studi Perbandingan Pengenalan Citra Senyuman Berdasarkan Aesthetic Dentistry Menggunakan Metode 2D-PCA Dan Metode 2D-LDA, http://kursor.trunojoyo.ac.id/wp-content/uploads/2012/03/vol5_no4_p2.pdf diakses tanggal 3 April 2014

[6] Damayanti, F., Arifin, A. Z., Soelaiman, R., 2010, Pengenalan Wajah Berbasis Metode TwoDimensional Linear Discriminant Analysis, Jurnal Kursor, Vol 5, No. 3, Hal 147-156.

[7] Sipahutar, J. P. A., Setiawardhana, Basuki, D. K., 2011, Sistem Identifikasi Smartcard-RFID dan Pengenalan Tanda Tangan Menggunakan Metode Backpropagation Dengan Kohonen Sebagai Pembanding, The $13^{\text {th }}$ Industrial Electronics Seminar 2011, Surabaya, 26 Oktober 2016.

[8] Pamungkas, D. P., Utami, E., Amborowati, A., 2015. Komparasi Pengenalan Citra Tanda Tangan dengan Metode 2D-PCA dan 2DLDA. Jurnal CITEC, Vol 2, No 4, Hal 341-354. 
Citec Journal, Vol. 3, No. 4, Agustus 2016 - Oktober 2016

[9] Ye, J., Janardan, R., Li, Q., 2005, Two-dimensional linear discriminant analysis, http://papers.nips.cc/paper/2547-two-dimensional-linear-discriminant-analysis.pdf, diakses tanggal 13 April 2015

[10] Farag, A. A., Elhabian, S. Y., 2008, A Tutorial on Data Reduction LDA, http://www.di.univr.it/documenti/OccorrenzaIns/matdid/matdid437773.pdf, diakses tanggal 11 April 2015

[11] Putra, D., 2009, Sistem Biometrika, Penerbit ANDI, Yogyakarta 